\title{
Molecular markers in ecology of ectomycorrhizal fungi
}

\author{
Francis Martin*, Marc-André Selosse ${ }^{1}$, Céline Di Battista, \\ Hassen Gherbi, Christine Delaruelle, Dominique Vairelles, \\ Daniel Bouchard, François Le Tacon \\ Équipe de microbiologie forestière, Centre de recherche de Nancy, \\ Institut national de la recherche agronomique, 54280 Champenoux, France
}

\begin{abstract}
Deoxyribonucleic acid (DNA) markers have been used in many studies to distinguish related species of ectomycorrhizal fungi or genotypes of a single species. These markers have been designed to identify defined strains of ectomycorrhizal fungi in forest nurseries and within the complex microbial communities of reforestation sites and natural ecosystems. Various polymerase chain reaction (PCR)-based methods revealed sequence polymorphisms in nuclear and mitochondrial ribosomal DNA of ectomycorrhizal fungi that can be used as highly informative markers for the structure and dynamics of genomes at the level of communities and populations. Markers based on random amplified polymorphic DNA (RAPD) or on microsatellite-primed PCR are suitable for identifying clones (genotypes) and describing the differentiation of populations of ectomycorrhizal fungi. Here we describe the procedures that allow the rapid typing of an ectomycorrhizal isolate from vegetative mycelium, fruiting bodies, as well as a single ectomycorrhizal root tip. Specific applications illustrated are: identification of fungal species and isolates; analysis of the persistence and dissemination of introduced exotic strains; and detection of gene flow between introduced strains and local forest populations. (c) Inra/Elsevier, Paris
\end{abstract}

ectomycorrhiza / population structure / RAPD / rDNA / RFLP

Résumé - Techniques moléculaires d'identification des champignons ectomycorhiziens. Quelques exemples d'applications en écologie. Les techniques de diagnostic moléculaire permettant d'identifier les différentes espèces de champignons ectomycorhiziens, ou les génotypes au sein de ces espèces, se sont considérablement développées au cours des dernières années. Plusieurs types de marqueurs moléculaires ont été mis au point pour identifier des souches de champignons ectomycorhiziens, aussi bien dans les pépinières forestières que dans les sites de reforestations et les écosystèmes naturels. Diverses méthodes, basées sur la PCR, sont utilisées pour caractériser le polymorphisme des ADN ribosomaux nucléaires et mitochondriaux

* Correspondence and reprints

** On leave from École nationale du génie rural, des eaux et forêts, Paris. 
de ces champignons. Ce polymorphisme a permis d'aborder la structuration et la dynamique des communautés et des populations naturelles de symbiotes ectomycorhiziens. L'analyse RAPD et les empreintes génétiques obtenues par amplification des régions intermicrosatellitaires permettent d'identifier les différents génotypes et de décrire la genèse des populations mycorhiziennes. Cet article fait la synthèse des méthodes de diagnostic moléculaire développées afin d'identifier les mycélia et fructifications de champignons ectomycorhiziens, ainsi que leurs ectomycorhizes. Ces outils nous ont permis d'analyser la persistance et la dissémination d'une souche fongique exotique (Laccaria bicolor $\mathrm{S} 238$ ) introduite en pépinières, puis en plantations. (C) Inra/Elsevier, Paris

ectomycorhize / structure des populations / RAPD / rDNA / RFLP

\section{INTRODUCTION}

Ectomycorrhizal symbiosis, a mutualistic plant-fungus association, plays a fundamental role in the biology and ecology of forest trees, affecting growth, water and nutrient absorption, and providing protection from root diseases (Smith and Read, 1997). In a forest ecosystem, roots are exposed to several different species of ectomycorrhizal fungi. Each species exists as a population of many individuals between which there is almost invariably some genetic variation (Debaud et al., 1995). The fact that trees are exposed to symbiont populations that are genetically diverse is an important consideration in forest ecology. Individual symbionts vary in their potential range of host species, ability to colonise different genotypes of host plant, ability to promote plant growth and adaptation to abiotic factors, such as soil pH. Each of these factors might affect the course of a beneficial symbiosis and the dissemination of an individual symbiont in a forest ecosystem. Questions about the temporal and spatial distributions of communities and populations of ectomycorrhizal fungi, together with the origin and maintenance of their genetic variation, are therefore critical when trying to understand how populations of ectomycorrhizal fungi evolve and disappear at different stages of development of forest ecosystems. By implication, such an understanding can help in the formulation of programmes where economically important tree species (e.g. eucalyptus, firs, pines, spruces) are inoculated using selected beneficial ectomycorrhizal fungi.

Mycorrhizal inoculation of seedlings with selected ectomycorrhizal fungi is now applied world-wide to improve the survival, establishment and growth of seedlings after outplanting (for a review, see Le Tacon et al., 1992; Grove and Le Tacon, 1993). The extent to which these benefits are realised at the planting sites depends on the rate of initial fungal colonisation, dissemination and persistence of the inoculated symbiotic fungus, and biotic and abiotic features specific to each site (Grove and Le Tacon, 1993). Successful mycorrhizal inoculations have mostly been obtained in nurseries (Le Tacon et al., 1992) and on former farmlands (Grove et al., 1991) where ectomycorrhizal communities are limited. In reforestation sites where indigenous ectomycorrhizal communities are large and competitive, local species may outcompete the artificially introduced isolates and result in no improvements in tree growth (Le Tacon et al., 1992). An assessment of the dissemination and survival of introduced fungal isolates in natural mycorrhizal communities would facilitate the design of large-scale inoculation programmes. 
In the last decade, molecular techniques have had a major impact on population genetics of ectomycorrhizal fungi (Egger, 1995). Before the 1990s, the markers that were available for identifying mycorrhizal fungi for population studies were morphological (Agerer, 1991) or were allozymes (Sen, 1990). Today, a wide range of techniques can be used to detect deoxyribonucleic acid (DNA) sequence variation in éctomycorrhizal fungi (Gardes et al., 1991a, b; Henrion et al., 1992; Bruns and Gardes, 1993; Egger, 1995; Selosse et al., 1996). They offer a new approach to answer old, intractable questions in mycorrhiza ecology, as well as new questions. Questions of current interest in the population genetics of mycorrhizal fungi include:

1) How do mycobiont populations establish and compete on a host plant?

2) To what extent does the introduction of a new genotype (e.g. a selected beneficial inoculum) in a forest ecosystem cause differentiation of new populations or disappearance of existing indigenous fungal populations?

3) How important is vegetative/sexual reproduction in the dissemination and maintenance of populations of ectomycorrhizal fungi?

Several procedures (ribosomal DNA [rDNA] typing, random amplified polymorphic DNA [RAPD], inter-repeat polymerase chain reaction $[\mathrm{PCR}]$ ) that allow the rapid identification of an ectomycorrhizal isolate using PCR of DNA extracted from vegetative mycelium, sporophores (= fruiting bodies), as well as a single ectomycorrhizal root tip, their uses and limitations are discussed here. The following selection of examples is not intended to be comprehensive, but rather to indicate the range of research in which DNA markers have been used. These applications include: identification of ectomycorrhizal fungi at the species and isolate levels; analysis of the survival and dissemination of introduced fungal inoculum; analysis of the introgression of exotic fungal strains in local forest populations; and spatial distribution of clonal populations (genets) of mycobionts.

\section{MOLECULAR TOOLS FOR TYPING ECTOMYCORRHIZAL FUNGI}

PCR amplification of targeted genomic sequences, followed by restriction fragment length polymorphism (RFLP) analysis, allele-specific hybridisation, direct sequencing and heteroduplex polymorphisms is increasingly used to detect and characterise microbes interacting with plants in natural ecosystems (Egger, 1995; Brown, 1996; Lubeck and Lubeck, 1996). As part of our current research effort to develop methods for use in the identification of ectomycorrhizal fungi, we have designed a set of procedures based on a PCR approach to type fungal genotypes found in forest nurseries, and beech, Norway spruce and Douglas fir stands. These procedures include: PCR/RFLP of the internal transcribed spacer (ITS) and the intergenic spacer (IGS) of rDNA and regions of the large mitochondrial rDNA (LrDNA), high-performance capillary electrophoresis (HPCE) of IGS heteroduplexes, RAPD and microsatellite-primed PCR (Henrion et al., 1992, 1994a, b; Martin et al., 1993; Erland et al., 1994; Di Battista et al., 1996; Selosse et al., 1996, 1998; Di Battista, 1997; Martin et al., 1998). The ultimate aim of these investigations is to set up an expandable database of DNA profiles and fingerprints of ectomycorrhizal fungi in a World Wide Web (WWW) Internet server (Martin and Martin, 1997) to be used for studies of below-ground communities of mycorrhizal roots in temperate forests. 


\subsection{Molecular identification of ectomycorrhizal fungi using rDNA spacers}

The nuclear rDNA unit provides useful inter- and intraspecific polymorphisms to type plant-associated fungi. In the latter organisms, there are multiple copies (40-100) of the ribosomal ribonucleic acid (rRNA) genes, which are arranged as head-to-tail repeats separated by noncoding spacers (figure $1 \mathrm{~A}$ ). They are located at one locus in most higher fungi and have identical sequences in a given nucleus due to concerted evolution (Srivasta and Schlessinger, 1991). The approach described herein is a general method that can be used to identify most fungi to the level of species or group of species. The identification scheme is based on the amplification of the ITS and/or IGS spacers of the rDNA unit, digestion with restriction enzymes, electrophoretic separation of the DNA fragments and side-by-side comparison of the resulting RFLP patterns to those produced by DNA from those of known species. Samples of known DNA may be derived from either mycelium cultures, identified fruiting bodies or herbarium specimens (Gardes et al., 1991a; Henrion et al., 1992; Gardes and Bruns, $1996 \mathrm{~b})$. Comparisons using three endonucleases, recognising four- or five-base recognition sequences, generally separate most species of ectomycorrhizal fungi (Gardes and Bruns, 1996a; Di Battista, 1997; Karen et al., 1997; Pritsch et al., 1997). We have used this PCR-RFLP approach to identify species of ectomycorrhizal fungi associated with Norway spruce and Douglas fir in nurseries and plantations in central and north-eastern France (Henrion et al., 1992; Di Battista, 1997; Selosse et al., 1998). PCR primers based on highly conserved regions of the rDNA unit have been designed (White et al., 1990; Henrion et al., 1992; Gardes and Bruns, 1993; Selosse et al., 1996) (figure 1B) to amplify the ITS and the IGS spacers. These noncoding regions are highly polymorphic and therefore provide a useful tool for molecular ecology. In addition, ITS region sequences can diagnose phylogenetic relationships at many phylogenetic levels (Hershkovitz and Lewis, 1996).

For assessing the variation in the rDNA spacers, total DNA was routinely extracted from vegetative mycelium, single ectomycorrhizal tips or from sporophores by the cetyltrimethylammonium bromide (CTAB) protocol according to Henrion et al. (1994a). For recalcitrant samples resulting in no amplification or low amplification, DNA was extracted using a guanidinium buffer followed by DNA purification using GeneClean glass beads (Grube et al., 1995; Martin et al., 1997). The rDNA ITS was amplified, using primers ITS1 and ITS4 ( figure 1B) or ITS1-F and ITS4-B (Gardes and Bruns, 1993) according to Henrion et al. (1994a). Intraspecific-level identification relied on the amplification of IGS1 and IGS2 using primers CNL12/5SA and rev5SA/revNS1, respectively (figure 1B; Selosse et al., 1996). The sequence variation of ITS and IGS regions was then characterised by digestion with widely available and cheap endonucleases, such as EcoRI, HinfI and RsaI (Henrion et al., 1992, 1994b). The resulting RFLPs were used to match fruiting bodies or mycelium of known species and unknown mycobionts associated with ectomycorrhizal tips. Our criterion for identification at the inter- and intraspecific levels was perfect RFLP matches between identified fungal material and unidentified ectomycorrhizas for single digests of the restriction enzyme HinfI and double digests using EcoRI and RsaI. 
(A)
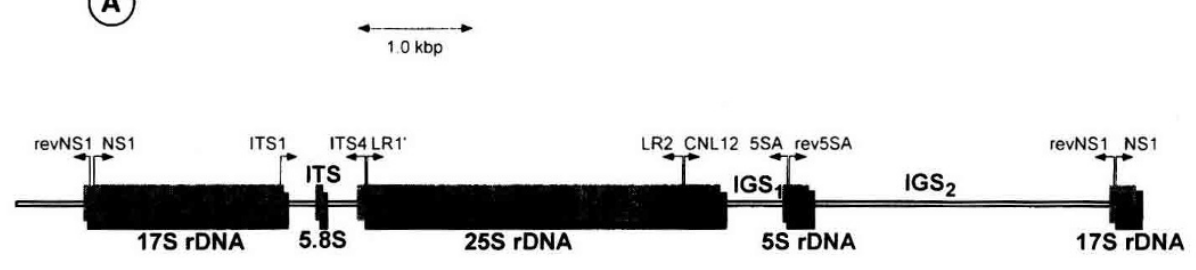

(B)

\begin{tabular}{|c|c|c|}
\hline Primers & Sequence $\left(5^{\prime}\right.$ to $\left.3^{\prime}\right)$ & Designed for: \\
\hline ITS1 & TCCGTAGGTGAACCTGCGG & internal transcribed spacer \\
\hline ITS4 & TCCTCCGCTTATTGATATGC & $"$ \\
\hline NS1 & GTAGTCATATGCTTGTCTC & $17 S$ rDNA \\
\hline LR1 & GCATATCAATAAGCGGAGGA & $25 S$ rDNA \\
\hline LR2 & GACTTAGAGGCGTTCAG & $"$ \\
\hline CNL12 & CTGAACGCCTCTAAGTCAG & intergenic spacer IGS1 \\
\hline $5 S A$ & CAGAGTCCTATGGCCGTGGAT & " \\
\hline rev5SA & ATCCACGGCCATAGGACTCTG & intergenic spacer IGS2 \\
\hline revNS1 & GAGACAAGCATATGACTAC & \\
\hline
\end{tabular}

Figure 1. (A) Diagram of a ribosomal DNA (rDNA) repeat of the basidiomycete Laccaria bicolor. Rectangles represent coding sequences for $17 \mathrm{~S}, 25 \mathrm{~S}$ and $5 \mathrm{~S}$ ribosomal RNA. Lines represent spacer sequences: IGS, intergenic spacer; ITS, internal transcribed spacer. The primer annealing sites are delineated as arrows near the coding sequences. (B) Primers used to amplify the ITS, IGS1, IGS2 and coding rDNA regions from ectomycorrhizal fungi.

\subsection{1. rDNA ITS as a species marker}

The ITS regions of the nuclear rDNA unit (figure 1A) are reported to exhibit a high degree of polymorphism between species, but are often highly conserved within species; thus, they contain valuable genetic markers for species identification (Bruns et al., 1991; Gardes and Bruns, 1996b). The inter- and intraspecific variation in the ITS region of ectomycorrhizal species associated with black alder, eucalyptus, oaks, pines, spruces and firs have been characterised (Henrion et al., 1992, 1994a; Erland et al., 1994; Gardes and Bruns, 1996a; Karen et al., 1997; Pritsch et al., 1997; Martin et al., 1998). These investigations made it possible to estimate the variation of the ITS region of fungal isolates sampled over wide geographical areas and of the reliability of the RFLP identification (see Karen et al., 1997 for a discussion).

The variation of RFLPs of the rDNA ITS between ectomycorrhizal species collected in forest nurseries, plantations and Norway spruce and Douglas fir forests of central and north-eastern France was high (Henrion et al., 1992; Di Battista, 1997), supporting previous views that this polymorphic rDNA region is well suited to identification of ectomycorrhizal species (Bruns et al., 1991; Gardes et al., 1991b; Henrion et al., 1992; Karen et al., 1997). In 
the investigated species, the size of the entire ITS region is in the range of 650-1000 bp and restriction digests exhibited from two to five fragments (Di Battista, 1997). Using the endonucleases HinfI, RsaI and EcoRI, it was possible to distinguish 53 of the 66 ectomycorrhizal species harvested in central and north-eastern France. The RFLP database section of our WWW site (Martin and Martin, 1997) displays a comprehensive set of the obtained PCR/RFLP patterns. Some closely related species do not differ enough from the ITS region to be distinguished with this marker (e.g. Laccaria bicolor and Laccaria laccata; Henrion et al., 1992). Other regions, such as the rDNA IGS (see later), are more useful than ITS in discriminating these closely related species.

The degree of interspecific variation in the ITS nucleotide sequence from several taxa of ectomycorrhizal fungi sampled at the investigated sites (e.g. Hebeloma crustuliniforme, Laccaria laccata, L. bicolor, Lactarius subdulcis, Thelephora terrestris, Amanita muscaria) was assessed by direct sequencing of the amplified ITS (Martin, unpublished results). The estimated pairwise distance among ITS sequences (2 to $58 \%$ ) was in the range found in some other fungal species (Bruns et al., 1991; Gardes et al., 1991b; Hibbett et al., 1995). Pairwise divergence between ITS sequences ranged from $3 \%$ between Laccaria species to $34 \%$ between members of the Tricholomatacaea (e.g. L. bicolor versus $T$. matsutake) to $55 \%$ between species of different taxonomic divisions (e.g. L. bicolor versus Tuber albidum). We also used direct sequencing analysis of the rDNA ITS region to identify fungal species forming ectomycorrhizal tips. We and others (Gardes and Bruns, 1996a) have a sequence database for over 100 species of 50 genera (Martin and Martin, 1997) in this rDNA region, and hundreds of additional ITS sequences of ectomycorrhizal fungi are available from the National Center for Biotechnology Information (GenBank) database. A match of 97-100\% between an unknown ectomycorrhizal type and an identified fungal material (e.g. a fruiting body collected at the mycorrhiza sampling site) generally indicates a set of closely related species.

Due to this high degree of interspecific variation of the ITS sequences, identical matches between RFLP types of mycorrhizas and reference RFLP types sampled within the same geographical area are likely to indicate identical species. However, some closely related species ( $L$. bicolor and L. laccata) may be grouped together by the three-enzyme match criterion, and more rarely, intraspecific differences may result in failure to recognise a species match (Di Battista, 1997; Karen et al., 1997). It should be kept in mind that, as the restriction fragments are not independent characters (Bruns et al., 1991), it is difficult to establish the genetic identity of samples with restriction patterns that do not match the reference RFLP types (Egger, 1995). Use of more highly conserved regions such as protein coding sequences (e.g. chitin synthases, glyceraldehyde-3-phosphate dehydrogenase; Lanfranco et al., 1995; Kreuzinger et al., 1996) may bypass this problem.

The results of our RFLP analysis showed that intraspecific ITS variation of investigated species was low, which is in accordance with previous studies of the ITS region of ectomycorrhizal fungi (Gardes et al., 1991; Gardes and Bruns, 1996a). Only a small proportion of the species that were analysed in the present survey had polymorphic intraspecific RFLPs in one or more of the enzymes used in this study (e.g. Lactarius rufus, L. hepaticus) (Di Battista, 1997). As the frequency of polymorphic species was low, and the typed isolates had widely 
separated origins (up to $200 \mathrm{~km}$ ), it is likely that intraspecific polymorphisms in the ITS region, if any, would occur mainly over a regional rather than on a local (i.e. forest) scale, but because intraspecific variation does exist, it is worthwhile using local isolates for RFLP matching. A large proportion of the ectomycorrhizas formed by the investigated species located in central and north-eastern France should be identified when compared with the present database of ITS RFLPs and sequences. Thus, it is possible to establish ITS references (RFLPs or sequences) without the need to include a large number of isolates/vouchers from each reference species. Similar conclusions have been drawn from surveys of the ectomycorrhizal community in natural stands of bishop pine (Gardes and Bruns, 1996a), black alder (Pritsch et al., 1997) and in Fennoscandian boreal forests (Karen et al., 1997).

\subsection{2. rDNA IGS as an isolate marker}

In higher fungi, the noncoding regions IGS1 (between the 25S and 5S coding units) and IGS2 (between the $5 \mathrm{~S}$ and $17 \mathrm{~S}$ coding units) (figure 1A), are known to present length and sequence variations within a species (Molina et al., 1993; Iraçabal and Labarrère, 1994). We examined the polymorphism of nuclear PCR-amplified rDNA IGS to evaluate its intraspecific genetic variability in an attempt to identify specific isolates of Laccaria bicolor, L. laccata, $L$. amethystina, Pisolithus tinctorius and various species of Tuberacaea (Henrion et al., 1992, 1994a, b; Selosse et al., 1996; Martin et al., 1998).

Primers corresponding to conserved sequences of the $25 \mathrm{~S}, 5 \mathrm{~S}$ and $17 \mathrm{~S}$ rRNA genes (figure $1 B$ ) could amplify the sequences upstream (IGS1) (figure 2) and downstream (IGS2) (figure $4 A$ ) of the $5 \mathrm{~S}$ gene of a wide range of ectomycorrhizal species (Henrion et al., 1992; Selosse et al., 1996). The extremely high level of inter- (figure 2) and intraspecific (Henrion et al., 1992; Selosse et al., 1998) variation in the IGS is a reflection of indels within the rDNA region as a result of the occurrence of repeated sequences (figure 3) (Selosse et al., 1996; Martin and Selosse, unpublished results). For example, each of the tested Laccaria isolates occurring in the Peyrat-le-Château nursery was distinguished using either size polymorphism or restriction digest analysis (Henrion et al., 1994b). The IGS is thus highly polymorphic within and between biological species of Laccaria (Selosse et al., 1998). Large size and restriction site polymorphisms in IGS between rDNA repeats have been shown in other fungal species (Bruns et al., 1991; Anderson and Stasovski, 1992; Gryta et al., 1997).

The use of the IGS region in population genetics of ectomycorrhizal fungi will depend on a thorough understanding of its inheritance and mechanisms of evolution. In several ectomycorrhizal basidiomycetes ( $L$. bicolor, L. amethystina, Paxillus involutus), amplification products of the IGS sequences upstream (IGS1) and downstream (IGS2) of the 5S gene are heterogeneous, showing three and two fragments (figure 4), respectively. A Mendelian inheritance of the IGS2 amplification pattern ( $22 \alpha$ haplotypes: $20 \beta$ haplotypes) was observed in $L$. bicolor $\mathrm{S} 238 \mathrm{~N}$ progeny, suggesting that all the rDNA arrays are located at a single locus, and that the two IGS2 fragments amplified from L. bicolor S238N are allelic (Selosse et al., 1996). The segregation analysis of the IGS1 amplification pattern showed that the 2.2 and $2.4 \mathrm{~kb}$ fragments of lower electrophoretic mobility were heteroduplexes formed during PCR denaturation/hybridisation 

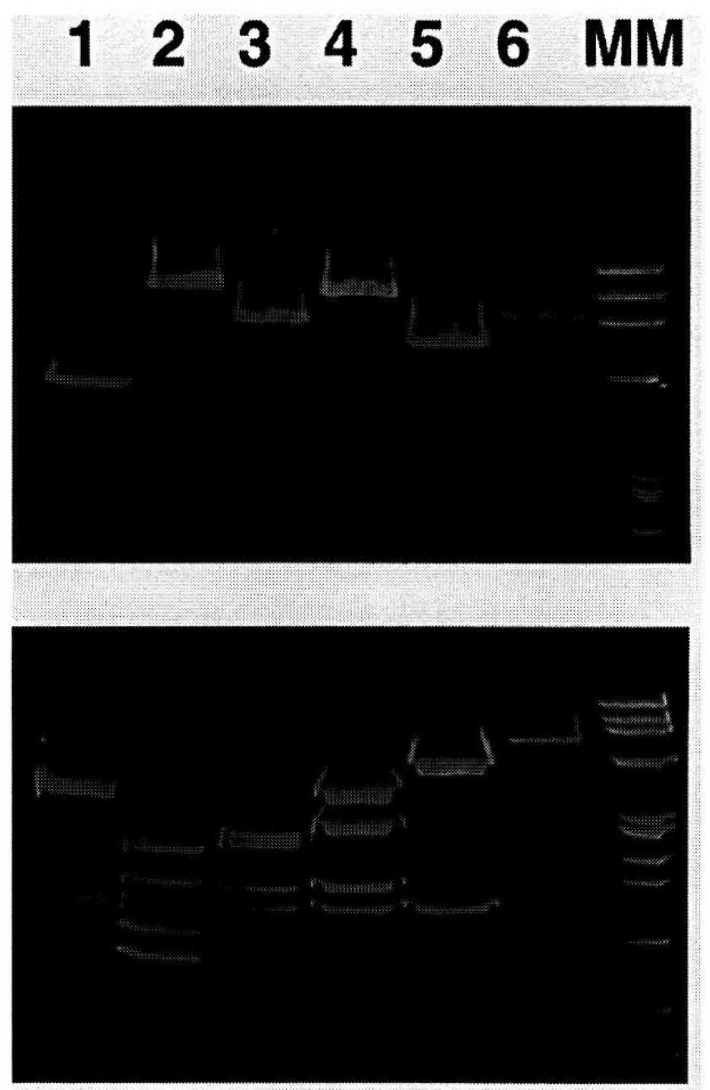

Figure 2. Interspecific polymorphism of ribosomal DNA (rDNA) IGS1 among ectomycorrhizal fungi sampled around the forest nursery of Peyrat-le-Château (HauteVienne, France). (A) Polymerase chain reaction (PCR) amplified IGS1. (B) HinfI restriction patterns; lane 1, Piloderma croceum; lane 2, Tricholoma coarctatum; lane 3, Scleroderma aurantium; lane 4, Hebeloma crustuliniforme; lane 5, Laccaria amethystina; lane 6, Paxillus involutus; MM, molecular weight marker ( $\Phi$ X174 DNA cut by HaeIII). Note the presence of heteroduplexes (=doublet with the higher size) in Piloderma croceum PCR products.

by cross-hybridisation between the two allelic IGS1. Formation of these heteroduplexes is due to the occurrence of $\mathrm{TA}_{2} \mathrm{C}_{3}$ repeats (figure 3) in variable number and allows the detection of rDNA heterozygosity (Selosse et al., 1996).

HPCE provides a rapid and automated technique for the analysis of subnanogram amounts of rDNA IGS generated by PCR (Martin et al., 1993). We used laser-induced fluorescent (LIF) detection to improve HPCE detection of multiple amplified IGS fragments of heterogeneous size corresponding to the homo/heteroduplexes (figure $4 B$ ). Amplifications were carried out using fluoroisothiocyanate FITC-labelled CNL12 or 5SA primers. Separation of FITClabelled homo/heteroduplexes was achieved in less than $30 \mathrm{~min}$ with the use of unpolymerised polyacrylamide gel as a sieving medium (figure 5). With LIF- 


\begin{abstract}
A
1 TCAACACTATTGTTGGACTTTTTCTCTTTTTTGTTTTAATCATGCTC

51 CTTGAGGGAGGTCATTTMACTTGGCCAT AGAGAGAGCATGTATGCTC

101 GAATGAATTTATAATA GAAGAATTATAACAAGACATTGTTATGTCAA

151 CTGCTTGGCTT AACTTGAGGGCAGGTCATTTTGACTTGGCCATRGCGGA

201 GAACATGACTATAGAAAAGACTACCAAAGTGAATAGAAACGTTGTAA

251 AGTGAACAGTGGAGTAAGTCAGAAAAGTCCTCTAAGTCGAAACCCTAACC

301 CTAACCCTAACCCAACCCTAA AACTACAAACCCTAACCCCTATTTGAA

351 TCACCATIGACTCTGTAACGGTGTTGAATCCATCTATTGACITTGAA;

401 TCTATTTTCGACGTTGTAPGACTITTTGATCTTTTCTGATGTTGAA

451 GTTGT TTTGAAGTTAAATAAAGTGGCTTATAGGGAGTGCAGAAACATTC

501 CAGAT
\end{abstract}

\title{
B
}

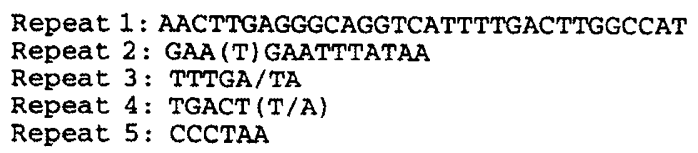

Figure 3. Sequence of the ribosomal DNA (rDNA) IGS1 region of Laccaria bicolor $\mathrm{S} 238 \mathrm{~N}$ and its relevant features (A) and the sequences of the major repeated elements (B). The 505 nucleotides present between the putative $3^{\prime}$ end of the $25 \mathrm{~S}$ rDNA and the $5^{\prime}$ end of the 5S rDNA of the $\alpha$ type allele (figure 4) are shown (GenBank accession $n^{\circ}$ L25898). Sequences of the major subrepeating elements and the $\mathrm{TA}_{2} \mathrm{C}_{3}$ repeat are boxed.

$\mathrm{HPCE}$, in contrast to slab gel electrophoresis, run times are short, the capillary can be reused and full automation is feasible. Data acquisition and analysis are computer-controlled, which facilitates the locus identification and reduces error, especially where large numbers of PCR products must be analysed (Martin et al., 1993).

In conclusion, length and sequence variations, and heteroduplex formation in the IGS of the rDNA, offer considerable potential to identify a specific isolate of ectomycorrhizal fungus and to investigate interstrain and progeny relationships.

\subsection{Mitochondrial typing using LrDNA}

Cytoplasmic markers, mainly mitochondrial, require special attention since their inheritance (Casselton and Economou, 1985) and population structure (Saville et al., 1996; Gryta et al., 1997) may differ from those of nuclear markers. Using primers designed to amplify the large mitochondrial subunit of mitochondrial rDNA (LrDNA) (White et al., 1990), cytoplasmic polymorphism has 


\section{monokaryons}
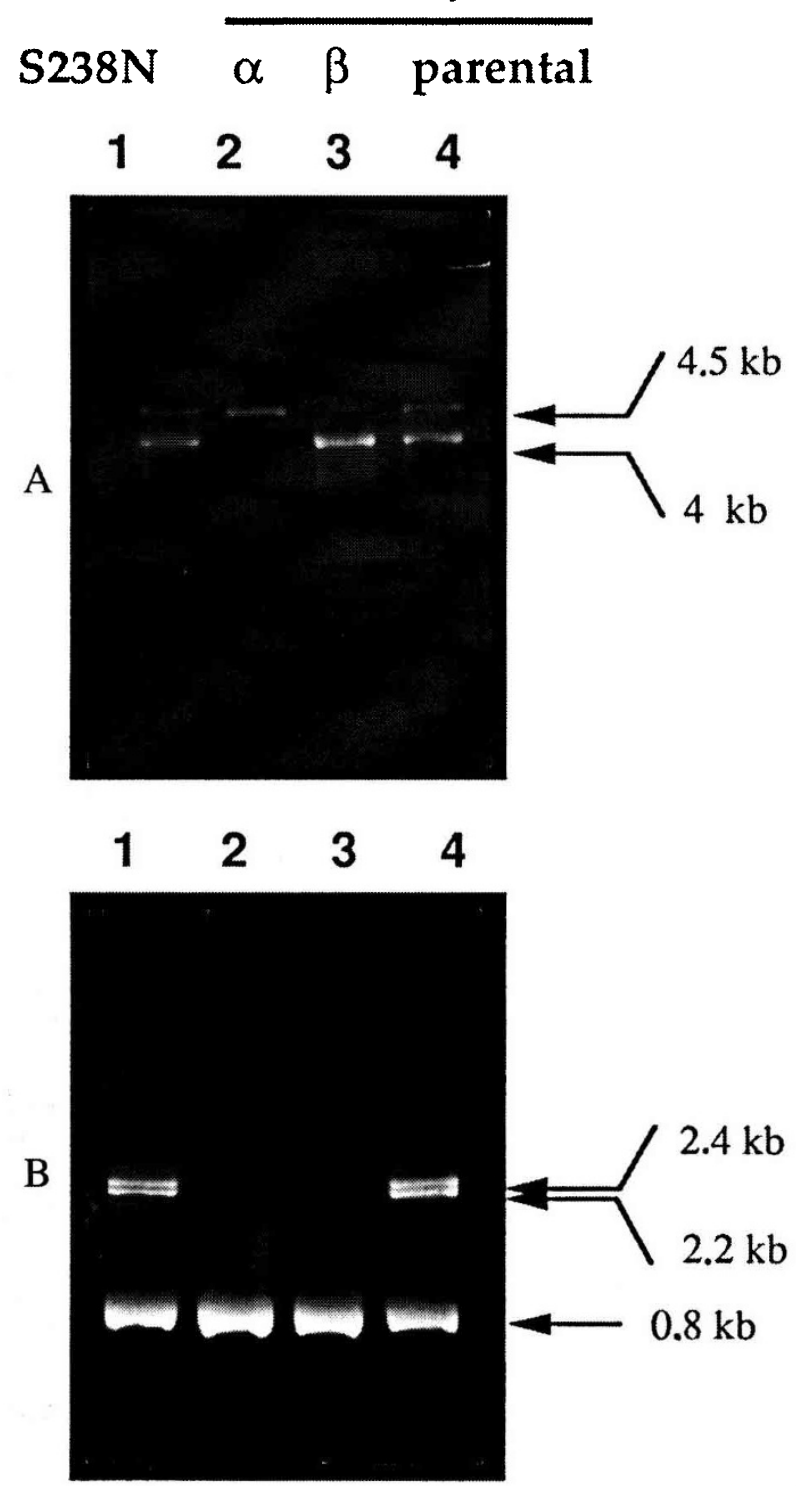

Figure 4. Segregation of amplified pattern of the ribosomal DNA (rDNA) IGS2 (A) and IGS1 (B) in Laccaria bicolor S238N progeny. Amplified IGS2 was separated on $1 \%$ agarose, whereas amplified IGS1 was separated on $8 \%$ acrylamide to reveal heteroduplexes. Lane 1, dikaryotic strain S238N; lane 2, monokaryon of $\alpha$ type; lane 3, monokaryon of $\beta$ type; lane 4, monokaryon with a parental pattern arising from intralocus recombination (after Selosse et al., 1996). 


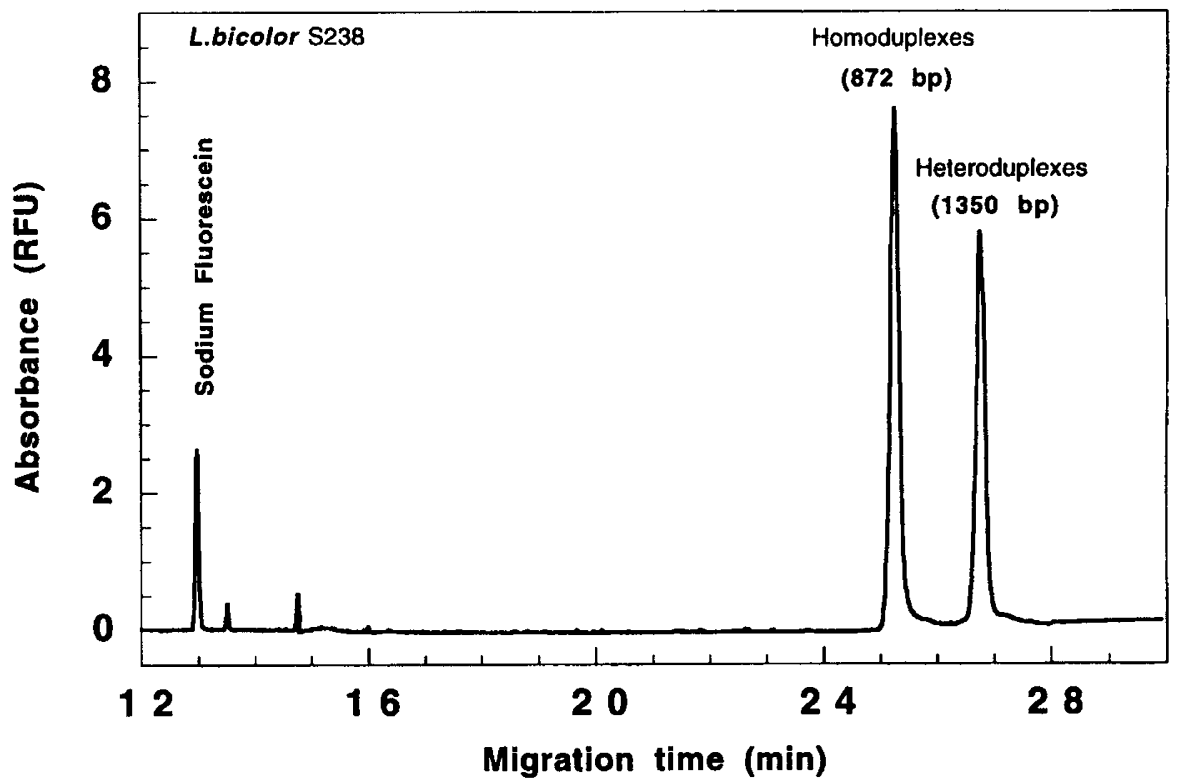

Figure 5. Separation by capillary electrophoresis, followed by laser-induced fluorescence detection, of the polymerase chain reaction (PCR)-amplified ribosomal DNA (rDNA) IGS1 of Laccaria bicolor S238N showing homoduplexes at $872 \mathrm{bp}$ and heteroduplexes at an apparent size of $1350 \mathrm{bp}$. Amplification was carried out using FITC-labelled CNL12 primer. Amplified products were directly injected in a highperformance capillary electrophoresis apparatus (P/ACE System 2100, Beckman Instruments) in the reverse polarity mode. The capillary cartridge (eCAP1000) contained a $57-\mathrm{cm}$ (50 $\mathrm{cm}$ to detector) fused silica capillary filled with unpolymerised acrylamide. The temperature of the capillary cartridge was set at $25^{\circ} \mathrm{C}$. Injection conditions: electrokinetic injection at $10 \mathrm{kV}$ for $15 \mathrm{~s}$. Analysis conditions: $175 \mathrm{~V} / \mathrm{cm}$ for $25 \mathrm{~min}$.

been reported in the genus Laccaria (Gardes et al., 1991a). We showed species polymorphism in the size of amplification products in Laccaria spp. (Selosse et al., unpublished results). Further polymorphism among amplification products of identical RFLP pattern was revealed using heteroduplex analysis. These heteroduplexes arise after denaturation and renaturation of purified amplification products with slightly different sequences (figure 6). Amplification length polymorphism and heteroduplex analysis are powerful tools for cytotyping of populations (Campbell et al., 1995).

\subsection{RAPD and microsatellite-primed PCR}

Another common use of molecular markers in population studies of fungal populations is to identify individual clones (= genets) in a partially sexual population (see Brown, 1996 for a review). Two fungal isolates are considered to be members of the same genet if they share all or most of a set of DNA fragments. For a better understanding of the diversity, structure and dynamics of populations of ectomycorrhizal fungi, genets have been identified on the basis 


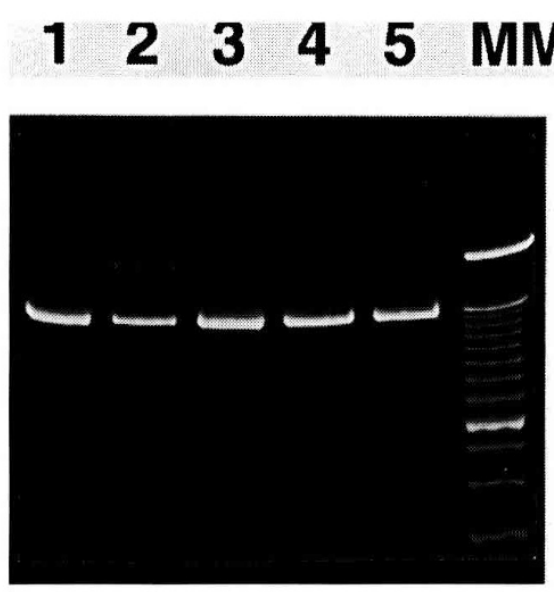

Figure 6. Heteroduplex formation among PCR products of the large mitochondrial subunit of rDNA (LrDNA) of Laccaria bicolor sporophores, distinguishing between nearly identical haplotypes. Mitochondrial LrDNA was amplified from Laccaria sporophores collected in Saint-Brisson (Nièvre, France; see table I) and from the collection strain L. bicolor S238N, using primers ML3 and ML6 (White et al., 1990). Lane 1, purified PCR product of a C-type L. bicolor sporophore; lane 2, purified PCR product of $L$. bicolor $\mathrm{S} 238 \mathrm{~N}$ and a C-type sporophore after joint denaturation: two low-mobility heteroduplexes appeared on the gel indicating sequence divergence; lane 3, purified PCR product of $L$. bicolor S238N; lane 4, purified PCR products of $L$. bicolor $\mathrm{S} 238 \mathrm{~N}$ and a B-type sporophore (i.e. with nuclear markers identical to $\mathrm{S} 238 \mathrm{~N}$; see table I) after joint denaturation: the absence of heteroduplex suggested an identical sequence for both fragments; lane 5, purified PCR product of a B-type L. bicolor sporophore; MM, molecular weight marker (100-bp ladder).

of their somatic incompatibility (Dahlberg and Stenlid, 1990). Unfortunately, this approach is time-consuming and can be inconclusive (Jacobson et al., 1993). RAPD (Welsh and McClelland, 1990; Williams et al., 1990) has been used successfully for the analysis of populations of Suillus granulatus (Jacobson et al., 1993) and Laccaria bicolor (de la Bastide et al., 1994; Doudrick et al., 1995; Selosse et al., 1998; see Section 3.2.2). A key assumption about genet identification is that DNA fragment sizes can be identified unambiguously. This can be a problem with RAPD, since some bands are difficult to amplify reproducibly (Tommerup et al., 1995). If the PCR conditions are defined stringently (annealing temperature $=55^{\circ} \mathrm{C}$ ), RAPD amplification is usually reproducible (Selosse et al., 1998).

Microsatellite-primed PCR, or inter-repeat PCR, has been used successfully to amplify hypervariable repetitive DNA sequences in a wide range of animal, plant and fungal species (Meyer et al., 1993; Longato and Bonfante, 1997). In this procedure, microsatellite oligonucleotides, that is, tandem repeats of short sequence motifs (mainly two to four nucleotides) [e.g. (GTG) $)_{5}$ ], are used as single PCR primers. If inversely repeated microsatellites are located in the genome within an amplifiable distance of one another, the inter-repeat sequences are amplified. Microsatellite-primed PCR has several advantages over RAPD analysis (e.g. use of high-stringency annealing conditions leading to 
reproducible DNA patterns) and over microsatellite analysis (e.g. no need for sequence information).

Primers corresponding to the microsatellite sequences $(\mathrm{GTG})_{5},(\mathrm{CA})_{8}$ and $(\mathrm{CT})_{8}$ annealed to genomic DNA and generated unique DNA fingerprints for each species of ectomycorrhizal fungi investigated (Martin et al., 1997). DNA from the species examined can be discriminated independently of the primer used. There is no similarity in the fingerprints generated from fungi of even closely related species (e.g. Laccaria spp.). Fingerprints of various genets of the ectomycorrhizal basidiomycete Laccaria amethystina collected in a 150-yearold beech stand in Aubure (Haut-Rhin) are shown in figure 7. The (GTG) 5- $^{-}$ primers yielded highly reproducible DNA fingerprints with five to 20 PCR products, ranging in size from approximately 0.2 to over $2 \mathrm{kbp}$ (Gherbi et al., unpublished results). Microsatellite-primed PCR, therefore, represents a useful tool for the identification of clone mates in populations of ectomycorrhizal fungi. Loci, detected by microsatellite-primed PCR, could be so variable that almost every individual is different.

Figure 8 shows a qualitative summary of DNA marker methods that we used in identifying ectomycorrhizal fungi and their useful ranges in systematics of these species. The necessary caveat is that equivalent taxonomic categories of different lineage often vary in terms of the degree of molecular divergence (Bruns et al., 1991). This means that selecting a DNA marker for a given investigation will almost always require an empirical survey.

\section{MONITORING THE PERSISTENCE OF LACCARIA BICOLOR AS AN ECTOMYCORRHIZAL SYMBIONT OF DOUGLAS FIR AND NORWAY SPRUCE}

A research programme has been developed in France over the last 15 years to improve growth and survival of Douglas fir (Pseudotsuga menziesii (Mirb.) Franco) and Norway spruce (Picea excelsa (Lam.) Link) by inoculation of the beneficial basidiomycete Laccaria bicolor S238N (Le Tacon et al., 1992). Laccaria species are ubiquitous symbiotic fungi, and are very common worldwide at nursery sites (Henrion et al., 1994b), but also in older forest stands (Baar et al., 1994). How the inoculated L. bicolor S238N colonises root systems and competes with the indigenous mycorrhizal populations in various ecosystems should be determined before its use in large-scale inoculation programmes (Villeneuve et al., 1991; Henrion et al., 1994b).

\subsection{Persistence of $L$. bicolor $\mathrm{S} 238 \mathrm{~N}$ in nurseries}

As emphasised earlier, to assess the effectiveness of the mycorrhizal inoculation of plants in a nursery, it is necessary to genotype the introduced strain and the competing local fungal species. This means estimating the number of short roots colonised by the various mycobionts. Variation in the ITS and IGS1 RFLP-types was used 1) to identify symbionts associated with nursery-grown Douglas fir and Norway spruce, and 2) to assess the persistence and dissemination of the introduced American L. bicolor S238N in the Peyrat-le-Château nursery (Henrion et al., 1994b; Di Battista, 1997). In these surveys, two sets of fungal isolates were compared: one corresponded to the local ectomycorrhizal 


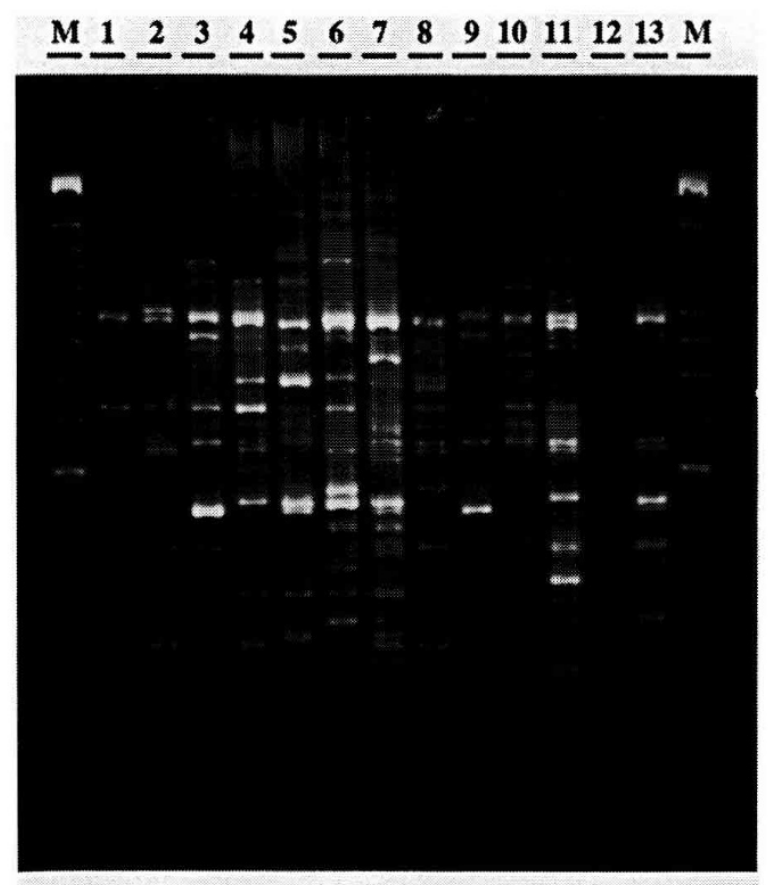

Figure 7. DNA fingerprints of various genotypes of Laccaria amethystina produced by microsatellite-primed polymerase chain reaction (PCR) using (GTG) ${ }_{5}$ as a single primer. 'Touchdown' PCR was carried out as follows: the thermal cycling started at an annealing temperature of $65^{\circ} \mathrm{C}$, which was reduced by $1{ }^{\circ} \mathrm{C}$ at each subsequent cycle to $58^{\circ} \mathrm{C}$. This was followed by 20 cycles at $94^{\circ} \mathrm{C}$ for $1 \mathrm{~min}, 55^{\circ} \mathrm{C}$ for $0.5 \mathrm{~min}$, and $72{ }^{\circ} \mathrm{C}$ for $1 \mathrm{~min}$, and then holding at $72^{\circ} \mathrm{C}$ for $10 \mathrm{~min}$. PCR products were separated on a Metaphor/agarose $(2 \% / 0.25 \%)$ gel. Lane $\mathrm{M}$ shows the DNA molecular size markers (100-bp BRL ladder), whereas lanes 1 to 13 correspond to DNA fingerprints of different sporophores collected at a $100 \mathrm{~m}^{2}$ plot in a 150 -year-old beech stand in Aubure (Haut-Rhin, France).

species which colonised noninoculated baiting-seedlings (i.e. control plants) after soil disinfection, whereas the second corresponded to fungal symbionts associated with $L$. bicolor $\mathrm{S} 238 \mathrm{~N}$-inoculated seedlings.

The IGS1-type of the reference isolate S238N (figure $4 B$ ) used to inoculate Douglas fir seedlings and Norway spruce cuttings was still the major IGS1profile associated with $L$. bicolor-treated seedlings two seasons of vegetation after fungal inoculation. Eighty percent of the ectomycorrhizal tips of 2-yearold Norway spruce plantlets were colonised by the American inoculant, whereas it colonised 80 to $99 \%$ of the Douglas fir root tips (table I). ITS- and IGS1types belonging to indigenous isolates (e.g. L. laccata Ind./Peyrat, Thelephora terrestris, Rhizopogon subaerolatus) were either not detected or represented less than $20 \%$ of the ectomycorrhizal tips. In contrast, noninoculated plantlets were abundantly colonised (up to $99 \%$ ) by local ectomycorrhizal species ( $L$. laccata Ind./Peyrat and T. terrestris), demonstrating the high level of natural inoculum potential of the nursery site. This study required the amplification of 


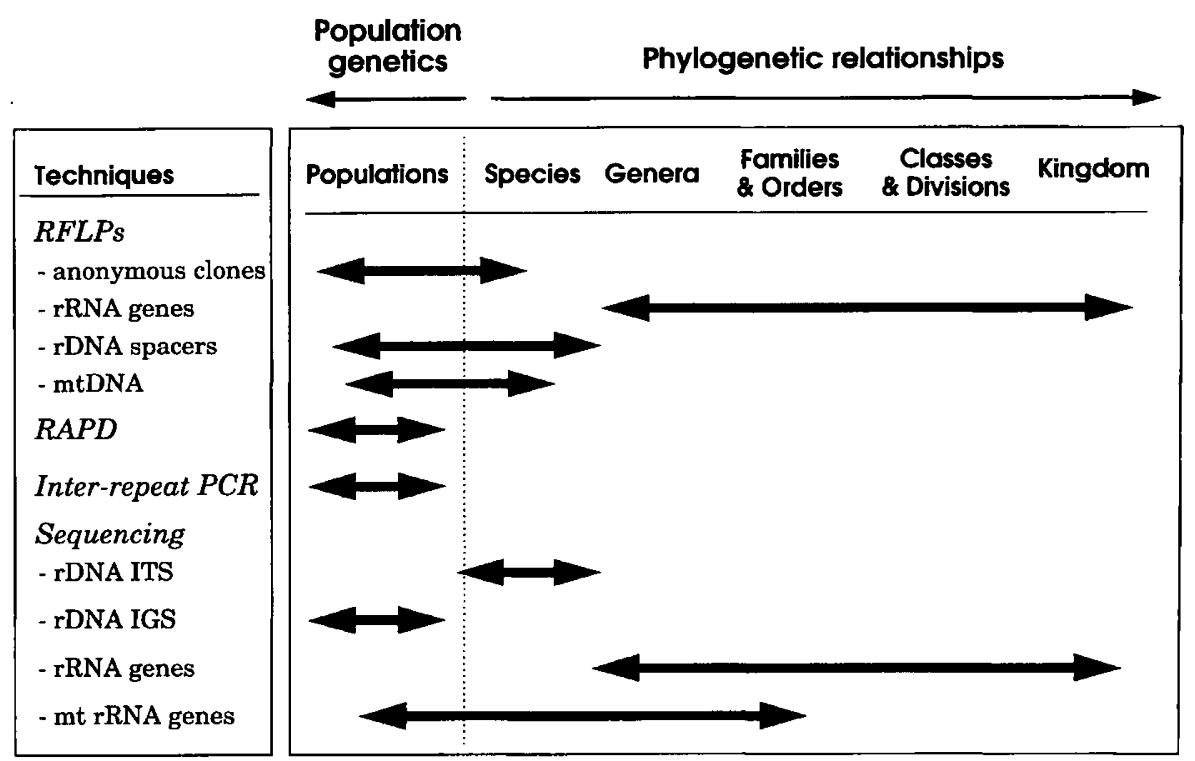

Figure 8. Qualitative summary of DNA markers and their useful ranges in the ecology and systematics of ectomycorrhizal fungi (adapted from Bruns et al., 1991). RFLP, restriction fragment length polymorphism; $r$, ribosomal; mt, mitochondrial; RAPD, random amplification of polymorphic DNA; PCR, polymerase chain reaction; ITS, internal transcribed spacers; IGS, intergenic spacer.

Table I. Nuclear and mitochondrial ribosomal DNA (rDNA) types of the nine genets found among 269 Laccaria spp. sporophores collected in 1995 on an inoculated Douglas fir plot in Saint-Brisson (France).

\begin{tabular}{lccccccccc}
\hline Nuclear genotype & A & B & C & D & E & F & G & H & I \\
Mitochondrial LrDNA type & I & II & I & I & I & III & III & III & III \\
Frequency* $^{*}$ & 14 & 100 & 23 & 48 & 15 & 17 & 30 & 14 & 8 \\
Species & \multicolumn{1}{c}{ Laccaria bicolor } & $\longrightarrow$ & & Laccaria laccata $\rightarrow$ \\
\hline
\end{tabular}

* Number of sporophores collected. LrDNA: large mitochondrial rDNA.

several hundreds of ectomycorrhizal tips and amplification yields were in the $70-80 \%$ range.

These data confirm and extend our previous study (Henrion et al., 1994b), indicating that the selected beneficial isolate $L$. bicolor $\mathrm{S} 238 \mathrm{~N}$ is sufficiently competitive to persist as an ectomycorrhizal associate of Douglas fir or Norway spruce at this nursery site and competed efficiently with local isolates of the same species. Plantlets leaving the nursery sites for outplanting (see later) were thus mainly colonised by the beneficial isolate. 


\subsection{Persistence of $L$. bicolor $S 238 \mathrm{~N}$ in plantations}

We used ITS- and IGS-typing, together with RAPD, to assess the survival of the American strain L. bicolor S238N on inoculated plantlets of Douglas fir and Norway spruce outplanted in forest stands (Di Battista, 1997; Selosse et al., 1998). This molecular analysis was carried out in plantations located in Saint Germain l'Herm (Puy-de-Dôme), Vidaillat (Creuse), Damelevières (Meurthe et Moselle) and Saint-Brisson (Nièvre).

\subsubsection{Persistence of L. bicolor S238N on Norway spruce}

Rooted cuttings of Norway spruce were inoculated using L. bicolor $\mathrm{S} 238 \mathrm{~N}$ on fumigated nursery soil. Inoculated plantlets, presenting a high rate of infection by S238N (see Section 3.1), were outplanted in a spruce/birch forest in Saint Germain l'Herm or in a chestnut/birch/oak forest in Vidaillat. Ectomycorrhizal roots of naturally mycorrhized or S238N-inoculated plants were sampled 2 and 4 years (Saint Germain l'Herm) or 3 years (Vidaillat) after outplanting and the ectomycorrhizal IGS1-types were assessed by heteroduplex analysis of PCRamplified IGS1 (see Section 2.2).

In Saint Germain l'Herm, the IGS1-type (figure $4 B$ ) of the inoculant strain $\mathrm{S} 238 \mathrm{~N}$ used to inoculate spruce cuttings was detected on 18 and $3 \%$ of the inoculated plants 2 and 4 years after outplanting, respectively (figure 9). Most of the ectomycorrhizal tips of control and inoculated Norway spruce plantlets were colonised by nonidentified ectomycorrhizal fungi. In the Vidaillat plantation, the inoculant strain $\mathrm{S} 238 \mathrm{~N}$ also disappeared rapidly since it represented only $15 \%$ of the ectomycorrhizal tips 1 year after outplanting (data not shown). Indigenous strains of ectomycorrhizal fungi associated with spruce, birch and oak present in the surroundings presumably outcompeted the introduced American strain and rapidly colonised the new root tips of the outplanted trees.

\subsubsection{Persistence of L. bicolor S238N on Douglas fir in Saint-Brisson}

Our study of the populations of the ectomycorrhizal L. bicolor and L. laccata in a Douglas fir plantation in central France (Saint-Brisson, Nièvre) is one of an increasing number of examples (Jacobson et al., 1993; de la Bastide et al., 1994, 1995) of the use of RAPD to analyse structured samples from ectomycorrhizal populations. In this case, Douglas fir seedlings were inoculated using L. bicolor $\mathrm{S} 238 \mathrm{~N}$ on fumigated nursery soil in 1985 (see Section 3.1) and outplanted 2 years later in a forest stand (Saint-Brisson, Nièvre). Eight years after outplanting (i.e. fall 1995), 269 sporophores were collected on a $150 \mathrm{~m}^{2}$ plot. Both L. bicolor and L. laccata sporophores were collected, since circumscription of European Laccaria species and their cross-fertility are unclear. After genotyping using heteroduplex analysis of the nuclear rDNA IGS1 and 51 RAPD markers, sporophores were shown to belong to four $L$. laccata genets and five L. bicolor genets, $37 \%$ of which, the so-called 'B-type', were shown to be identical to L. bicolor S238N (figure 10; table I) (Selosse et al., 1998). Typing of B-type LrDNA (see Section 2.2) suggested that its mitochondrial genome was identical to S238N, but different from DNA of the indigenous isolates (table $I$ ). 


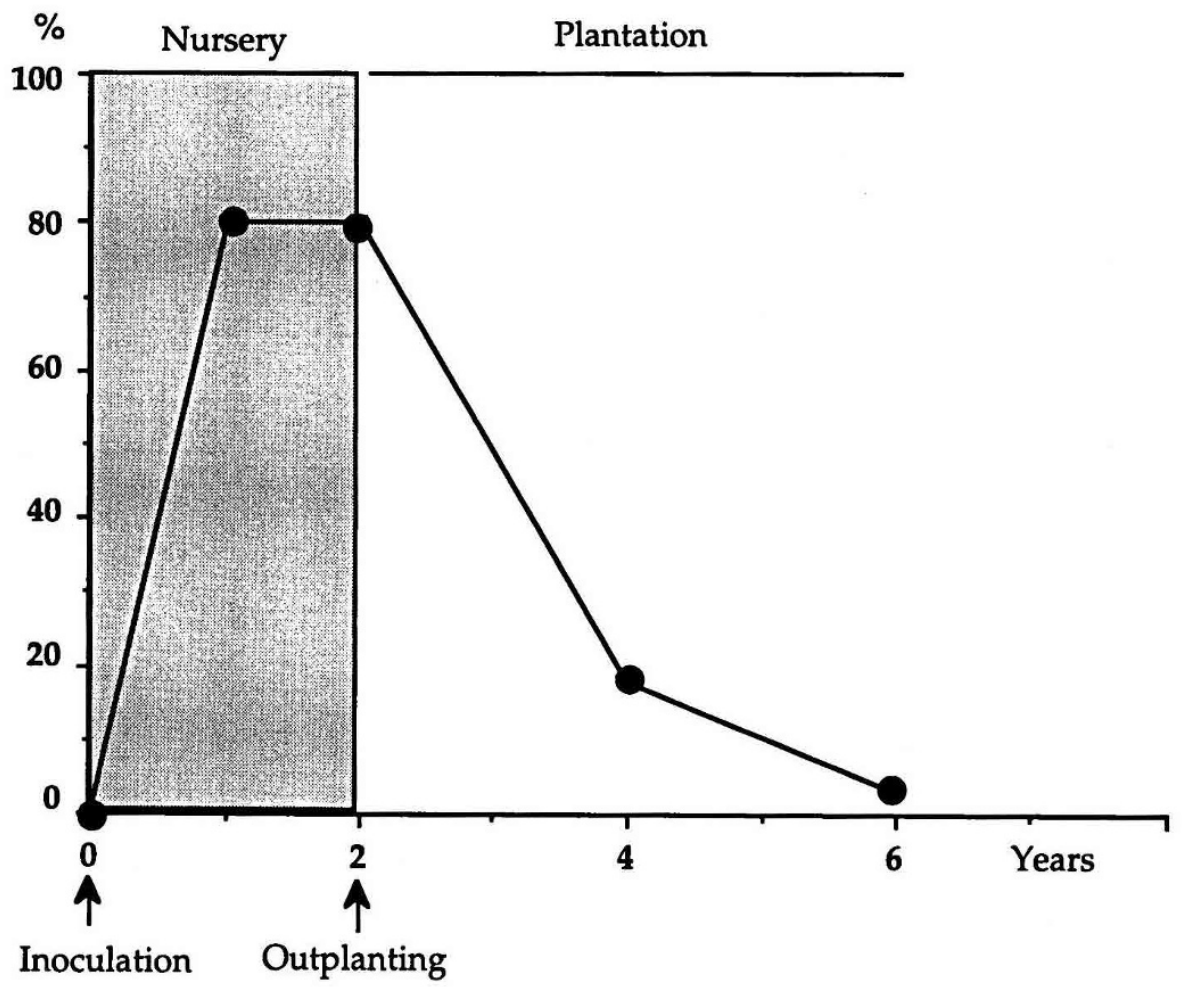

Figure 9. Persistence (expressed as $\%$ of total short roots) of the inoculated $L$. bicolor $\mathrm{S} 238 \mathrm{~N}$, as a symbiont of Norway spruce, in the nursery and after outplanting in the forest plantation of Saint Germain l'Herm (Puy-de-Dôme, France). Norway spruce was inoculated as described in Henrion et al. (1994b). Two-year-old inoculated plantlets were then outplanted (1800 plants/ha) in a former Norway spruce/birch site. The percentage of $L$. bicolor $\mathrm{S} 238 \mathrm{~N}$ ectomycorrhizas in total short roots was determined by polymerase chain reaction/restriction fragment length polymorphism (PCR-RFLP) of the ribosomal DNA (rDNA) internal transcribed spacers (ITS) and heteroduplex analysis of the rDNA intergenic spacer sequences upstream (IGS1).

During a 3-year survey (1994-1996) of various neighbouring plots, nuclear and cytoplasmic markers showed that L. bicolor $\mathrm{S} 238 \mathrm{~N}$ was still present on inoculated plots in the Saint-Brisson plantation 7 to 9 years after outplanting. It accounted for about $39 \%$ of 429 collected Laccaria sporophores. However, the inoculant $\mathrm{S} 238 \mathrm{~N}$ was never detected in control plots, where uninoculated plantlets were introduced, indicating that the inoculant $\mathrm{S} 238 \mathrm{~N}$ has a limited dissemination ability (Selosse et al., 1998).

Analysis of RAPD markers also showed that gene flow was indetectible between the introduced North American L. bicolor S238N and indigenous L. bicolor genets (Selosse et al., 1998). This lack of introgression was unexpected, since North American $L$. bicolor sensu lato have been reported to be genetically divergent from, but at least somewhat intercompatible with, European strains (Mueller and Gardes, 1991; de la Bastide et al., 1995). The cause of re- 


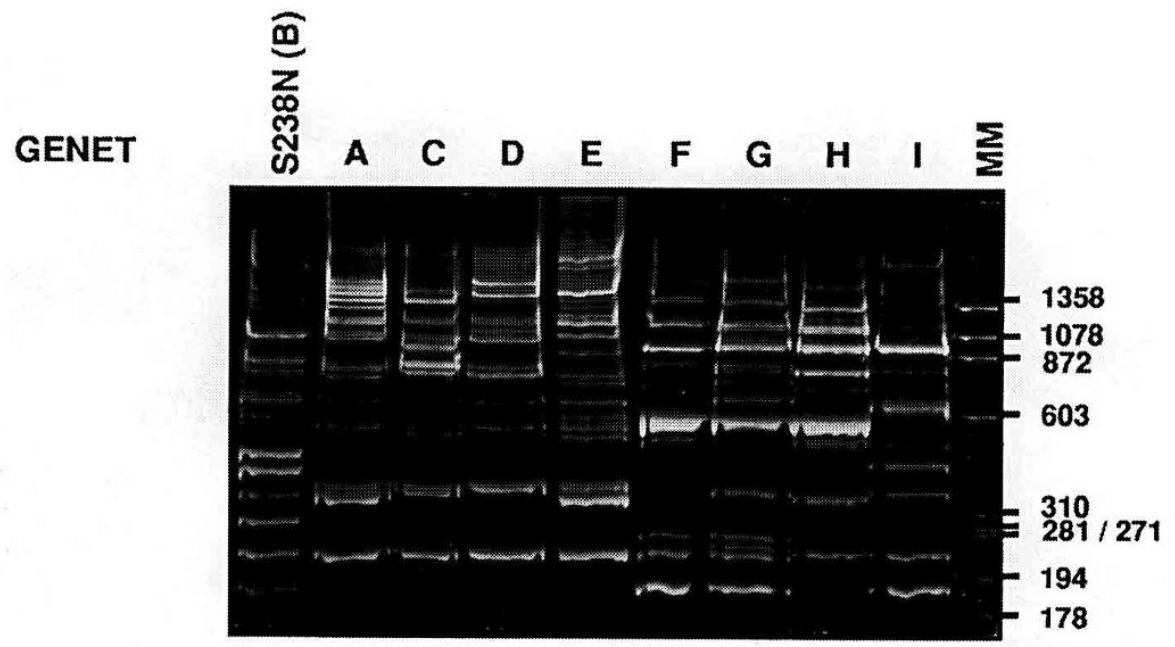

Figure 10. Comparison of random amplification of polymorphic DNA (RAPD) patterns from the eight indigenous genets (A to I; see table $I$ ) of Laccaria spp. and the inoculated Laccaria bicolor S238N (= type B) present on S238-inoculated Douglas first in a plantation at Saint-Brisson (Nièvre, France). RAPD products were obtained with primer $152-\mathrm{C}$ and were separated on $8 \%$ acrylamide. The size of the markers (bp, lane MM) is given on the right.

stricted gene flow between populations of $L$. bicolor is not known, but possible explanations include outbreeding depression due to geographical isolation and selection for biotypes of the symbiont adapted to different host plants and/or environments.

Data obtained in the Saint-Brisson plantation constitute, to our knowledge, the first evidence of genetically stable persistence over 9 years of an introduced fungal strain in natural populations. This may explain the significantly higher growth of the inoculated trees, as suggested in other studies (Villeneuve et al., 1991; Buschena et al., 1992; Le Tacon et al., 1992). The long-term persistence of $L$. bicolor $\mathrm{S} 238 \mathrm{~N}$ on Douglas fir in Saint-Brisson is in contrast to the limited persistence of this strain in plantations of inoculated Norway spruce (Section 3.2.1; figure 9). Due to the American origin of S238N, Douglas fir is likely a more suitable host for this strain. In addition, unknown abiotic factors specific to the individual forest sites certainly influence the survival of the introduced strain. Results from Norway spruce were obtained from ectomycorrhizal tips, not from the sporophores that may not mirror the above-ground population. Persistence of L. bicolor $\mathrm{S} 238 \mathrm{~N}$ as a symbiont on Douglas fir roots is currently being investigated by IGS1-typing of ectomycorrhizal tips.

In conclusion, inoculation of Douglas fir plantlets with the American $L$. bicolor $\mathrm{S} 238 \mathrm{~N}$ can lead to lasting infection with very limited effect on indigenous biodiversity at the genetic (no introgression) and ecological level (no invasion of uninoculated plots). A longer-term study of inoculated forests is further required, e.g. for understanding the differences with the $L$. bicolor $\mathrm{S} 238 \mathrm{~N} /$ spruce association. 


\section{CONCLUSION}

The investigations that we have carried out on the populations of ectomycorrhizal fungi in forest nurseries and plantations have demonstrated that tracking specific loci associated with a strain in below- and above-ground populations of ectomycorrhizal symbionts is possible. The simplest strategy of digesting PCRamplified ITS with selected endonucleases was effective in identifying species of ectomycorrhizal fungi (Henrion et al., 1994b; Di Battista, 1997). This ITSRFLP matching approach can be improved by obtaining sequence data on the targeted DNA followed by comparison with sequence databases. At the population level, heteroduplex analysis can be used to detect polymorphism in amplified products of ectomycorrhizal isolates (Di Battista, 1997; Selosse et al., 1998). This approach will be further facilitated by the use of HPCE, in conjunction with fluorescent primers.

Microsatellite-primed PCR and RAPD, as well as mitochondrial LrDNA and IGS amplification, represent useful tools for the identification of genets of ectomycorrhizal fungi. They have been used to analyse genetic structures of fungal populations and to assess gene flux between introduced strains and local populations (Selosse et al., 1998).

These molecular techniques have made it possible to monitor introduced beneficial mycorrhizal strains, together with indigenous ectomycorrhizal fungi, in nurseries, plantations and natural ecosystems. As a striking example, the persistence and dissemination of the beneficial L. bicolor S238N on Douglas fir was evaluated at a nursery site and in plantations several years after outplanting. Our molecular evidence for the persistence of the introduced mycorrhizal strain $\mathrm{S} 238 \mathrm{~N}$, despite the competition from local isolates of the same species (e.g. Saint-Brisson), provides additional proof of the potential of exotic species for large-scale mycorrhizal application. For practical use, the ability of an introduced ectomycorrhizal inoculant to survive and potentially flourish beyond the time period and place originally intended is important. However, rapid disappearance of the introduced strain from several spruce plantations (Vidaillat, Saint Germain l'Herm) suggested that the survival of the beneficial selected symbiont may be compromised when the competition by local strains is intense or when unknown biotic and abiotic factors are operative. Investigations are currently underway to identify these factors controlling the survival and dissemination of introduced ectomycorrhizal strains.

\section{ACKNOWLEDGEMENTS}

This work was supported by grants from the Bureau des Ressources Génétiques and the Ministère de l'Environnement, and by an EU contract (PL 931742). We would like to thank D. Jacquot and B. Bernier for help in typing sporophores and the company France-Foretts, owner of the Saint-Brisson stand, for access to the experimental plots. We also thank B. Genere and the CEMAGREF for their assistance. 


\section{REFERENCES}

Agerer R., Characterization of ectomycorrhiza, in: Norris J.R., Read D.J., Varma A.K. (Eds.), Methods in Microbiology. Techniques for the Study of Mycorrhiza, Academic Press, London, 23 (1991) 25-74.

Anderson J.B., Stasovski E., Molecular physiology of Northern Hemisphere species of Armillaria, Mycologia 84 (1992) 505-516.

Baar J., Ozinga W.A., Kuyper T.W., Spatial distribution of Laccaria bicolor genets reflected by sporocarps after removal of litter and humus layers in a Pinus sylvestris forest, Mycol. Res. 98 (1994) 726-728.

Brown J.K.M., The choice of molecular marker methods for population genetic studies of plant pathogens, New Phytol. 133 (1996) 183-195.

Bruns T., Gardes M., Molecular tools for the identification of ectomycorrhizal fungi - taxon-specific oligonucleotide probes for suilloid fungi, Mol. Ecol. 2 (1993) 233-242.

Bruns T., White T.J., Taylor J.W., Fungal molecular systematics, Annu. Rev. Ecol. Syst. 22 (1991) 525-564.

Buschena C.A., Doudrick R.L., Anderson N.A., Persistence of Laccaria spp. as ectomycorrhizal symbionts of container-grown black-spruce, Can. J. For. Res. 22 (1992) 1883-1887.

Campbell N.J.H., Hariss F.C., Elphinstone M.S., Baverstock P.R., Outgroup heteroduplex analysis using temperature gradient gel electrophoresis: high resolution, large scale, screening of DNA variation in the mitochondrial control region, Mol. Ecol. 4 (1995) 407-418.

Casselton L.A., Economou A., Dikaryon formation, in: Moore D., Casselto L.A., Wood D.A., Frankland J.C. (Eds.), Developmental Biology of Fungi, Cambridge University Press, Cambridge, 1985, pp. 213-229.

Dahlberg A., Stenlid J., Population structure and dynamics in Suillus bovinus as indicated by spatial distribution of fungal clones, New Phytol. 115 (1990) 487-493.

Debaud J.C., Marmeisse R., Gay G., Intraspecific genetic variation in ectomycorrhizal fungi, in: Varma A.K., Hock B. (Eds.), Mycorrhiza: Structure, Molecular Biology and Function, Springer-Verlag, Berlin, Heidelberg, 1995, pp. 79-113.

de la Bastide P.Y., Kropp B.R., Piché Y., Spatial distribution and temporal persistence of discrete genotypes of the ectomycorrhizal basidiomycete Laccaria bicolor (Maire) Orton, New Phytol. 127 (1994) 547-556.

de la Bastide P.Y., Kropp B.R., Piché Y., Population structure and mycelial phenotypic variability of the ectomycorrhizal basidiomycete Laccaria bicolor (Maire) Orton, Mycorrhiza 5 (1995) 371-379.

Di Battista C., Comportement en pépinière et en plantation d'un champignon ectomycorhizien Laccaria bicolor S238N inoculé sur Épicea (Picea abies) et Douglas (Pseudotsuga menziesii), Ph.D. thesis, University Henri Poincaré, Nancy, France, 1997.

Di Battista C., Selosse M.-A., Bouchard D., Stenström E., Le Tacon F., Variations in symbiotic efficiency, phenotypic characters and ploidy level among different isolates of the ectomycorrhizal basidiomycete Laccaria bicolor strain S238, Mycol. Res. 100 (1996) 1315-1324.

Doudrick R.L., Raffle V.L., Nelson C.D., Furnier G.R., Genetic analysis of homokaryons from a basidiome of Laccaria bicolor using random amplified polymorphic DNA (RAPD) markers, Mycol. Res. 99 (1995) 1361-1366.

Egger K.N., Molecular analysis of ectomycorrhizal fungal communities, Can. J. Bot. 73 (1995) S1415-S1422.

Erland S., Henrion B., Martin F., Glover L.A., Alexander I.J., Identification of the ectomycorrhizal basidiomycete Tylospora fibrillosa by RFLP analysis of the PCRamplified ITS and IGS regions of ribosomal DNA, New Phytol. 126 (1994) 525-532. 
Gardes M., Bruns T.D., ITS primers with enhanced specificity for basidiomycetes: application to the identification of mycorrhizae and rusts, Mol. Ecol. 2 (1993) 113-118.

Gardes M., Bruns T.D., Community structure of ectomycorrhizal fungi in a Pinus muricata forest: above- and below-ground views, Can. J. Bot. 74 (1996a) 1572-1583.

Gardes M., Bruns T.D., ITS-RFLP matching for identification of fungi, Species Diagnostics Protocols 50 (1996b) 177-186.

Gardes M., Mueller G.M., Fortin J.A., Kropp B.R., Mitochondrial DNA polymorphisms in Laccaria bicolor, L. laccata, L. proxima and L. amethystina, Mycol. Res. 95 (1991a) 206-216.

Gardes M., White T.J., Fortin J.A., Bruns T.D., Taylor J.W., Identification of indigenous and introduced symbiotic fungi in ectomycorrhizæ by amplification of nuclear and mitochondrial ribosomal DNA, Can. J. Bot. 69 (1991b) 180-190.

Grove T.S., Le Tacon F., Mycorrhiza in plantation forestry, Adv. Plant Pathol. 23 (1993) 191-227.

Grove T.S., Malajczuk N., Burgess T., Thomson B.D., Hardy G., Growth responses of plantation eucalypts to inoculation with selected ectomycorrhizal fungi, in: Intensive Forestry: The Role of Eucalypts, IUFRO, Durban, South Africa, 1991, pp. $86-93$.

Grube M., Depriest P.T., Gargas A., Hafellner J., DNA isolation from lichen ascomata, Mycol. Res. 99 (1995) 1321-1324.

Gryta H., Debaud J.-C., Effosse A., Gay G., Marmeisse R., Fine scale structure of populations of the ectomycorrhizal fungus Hebeloma cylindrosporum in coastal sand dune forest ecosystems, Mol. Ecol. 6 (1997) 353-364.

Henrion B., Le Tacon F., Martin F., Rapid identification of genetic variation of ectomycorrhizal fungi by amplification of ribosomal RNA genes, New Phytol. 122 (1992) 289-298.

Henrion B., Chevalier G., Martin F., Typing truffle species by PCR amplification of the ribosomal DNA spacers, Mycol. Res. 98 (1994a) 37-43.

Henrion B., Di Battista C., Bouchard D., Vairelles D., Thompson B.D., Le Tacon F., Martin F., Monitoring the persistence of Laccaria bicolor as an ectomycorrhizal symbiont of nursery-grown Douglas fir by PCR of the rDNA intergenic spacer, Mol. Ecol. 3 (1994b) 571-580.

Hershkovitz M.A., Lewis L.A., Deep-level diagnostic value of the rDNA-ITS region, Mol. Biol. Evol. 13 (1996) 1276-1295.

Hibbett D.S., Fukusama-Nakai Y., Tsuneda A., Donoghue M.J., Phylogenetic diversity in shiitake inferred from nuclear ribosomal DNA sequences, Mycologia 87 (1995) 618-638.

Iraçabal B., Labarrère J., Restriction site and length polymorphism of the rDNA unit in the cultivated basidiomycete Pleurotus cornucopiae, Theor. Appl. Genet. 88 (1994) 824-830.

Jacobson K.M., Miller O.K., Turner B.J., Randomly amplified polymorphic DNA markers are superior to somatic incompatibility tests for discriminating genotypes in natural populations of the ectomycorrhizal fungus Suillus granulatus, Proc. Natl. Acad. Sci. USA 90 (1993) 9159-9163.

Karen O., Högberg N., Dahlberg A., Jonsson L., Nylund J.E., Inter- and intraspecific variation in the ITS region of rDNA of ectomycorrhizal fungi in Fennoscandia as detected by endonuclease analysis, New Phytol. 136 (1997) 313-325.

Kreuzinger N., Podeu R., Gruber F., Gobl F., Kubicek C.P., Identification of some ectomycorrhizal basidiomycetes by PCR amplification of their gpd (glyceraldehyde-3-phosphate dehydrogenase) genes, Appl. Environ. Microb. 62 (1996) 3432 3438 .

Lanfranco L., Garnero L., Delpero M., Bonfante P., Chitin synthase homologs in three ectomycorrhizal truffles, FEMS Microbiol. Lett. 134 (1995) 109-114. 
Le Tacon F., Alvarez I.F., Bouchard D. et al., Variations in field response of forest trees to nursery ectomycorrhizal inoculation in Europe, in: Read D.J., Lewis D.H., Fitter A.H., Alexander I.J. (Eds.), Mycorrhizas in Ecosystems, CAB International, Wallingford, 1992, pp. 119-134.

Longato S., Bonfante P., Molecular identification of mycorrhizal fungi by direct amplification of microsatellite regions, Mycol. Res. 101 (1997) 425-432.

Lubeck M., Lubeck P.S., PCR-based methods - a promising tool for detection and identification of fungi in soil, in: Jensen D.F., Jansson H.B., Tronsmo A. (Eds.), Monitoring Antagonistic Fungi Deliberately Released into the Environment, Kluwer Academic Publishers, Dordrecht, 1996, pp. 113-122.

Martin F., Martin D., http://mycor.nancy.fr/Documents/MolEcol/MolEcolHome. html, 1997.

Martin F., Vairelles D., Henrion B., Automated ribosomal DNA fingerprinting by capillary electrophoresis of PCR products, Anal. Biochem. 214 (1993) 182-189.

Martin F., Costa G., Delaruelle C., Diez J., Genomic fingerprinting of ectomycorrhizal fungi by microsatellite-primed PCR, in: Varma A., Hock B. (Eds.), Mycorrhiza Manual, Springer Lab Manual, Berlin, Heidelberg, 1997.

Martin F., Delaruelle C., Ivory M., Genetic variability in intergenic spacers of ribosomal DNA in Pisolithus isolates associated with pine, eucalyptus and Afzelia in Lowland Kenyan forests, New Phytol. 139 (1998) 341-352.

Meyer W., Mitchell T.G., Freedman E.Z., Vilgalys R., Hybridization probes for conventional DNA fingerprinting used as single primers in the polymerase chain reaction to distinguish strains of Cryptococcus neoformans, J. Clin. Microbiol. 31 (1993) 2274-2280.

Molina F.I., Jong S.-C., Huffman J.L., PCR amplification of the $3^{\prime}$ external transcribed and intergenic spacers of the ribosomal DNA repeat unit in three species of Saccharomyces, FEMS Microbiol. Lett. 108 (1993) 259-264.

Mueller G.M., Gardes M., Intra- and interspecific relations within Laccaria bicolor sensu lato, Mycol. Res. 95 (1991) 592-601.

Pritsch K., Boyle H., Munch J.C., Buscot F., Characterisation and identification of black alder ectomycorrhizas by PCR/RFLP analyses of the rDNA internal transcribed spacer (ITS), New Phytol. 137 (1997) 357-369.

Saville B.J., Yoell H., Anderson J.B., Genetic exchange and recombination in populations of the root-infecting fungus Armillaria gallica, Mol. Ecol. 5 (1996) 485498.

Selosse M.-A., Costa G., Di Battista C., Le Tacon F., Martin F., Segregation and recombination of ribosomal haplotypes in the ectomycorrhizal basidiomycete Laccaria bicolor monitored by PCR and heteroduplex analysis, Curr. Genet. 30 (1996) 332-337.

Selosse M.-A., Jacquot D., Bouchard D., Martin F., Le Tacon F., Temporal persistence and spatial distribution of an American inoculant strain of the ectomycorrhizal basidiomycete Laccaria bicolor in European forest plantations, Mol. Ecol. 7 (1998) 561-573.

Sen R., Isozymic identification of individual ectomycorrhizas synthesized between Scots pine (Pinus sylvestris L.) and isolates of two species of Suillus, New Phytol. 114 (1990) 617-626.

Smith S.E., Read D.J., Mycorrhizal Symbiosis, 2nd ed., Academic Press, New York, 1997.

Srivastava A.K., Schlessinger D., Structure and organization of ribosomal DNA, Biochimie 73 (1991) 631-638.

Tommerup I.C., Barton J.E., O'Brien P.A., Reliability of RAPD fingerprinting of three basidiomycete fungi, Laccaria, Hydnangium and Rhizoctonia, Mycol. Res. 99 (1995) 179-186. 
Villeneuve N., Le Tacon F., Bouchard D., Survival of inoculated Laccaria bicolor in competition with native ectomycorrhizal fungi and effects on the growth of outplanted Douglas-fir seedlings, Plant Soil 135 (1991) 95-170.

Welsh J., McClelland M., Fingerprinting genomes using PCR with arbitrary primers, Nucleic Acids Res. 18 (1990) 7213-7218.

Williams J.G.K., Kubelik A.R., Livak K.J., Rafalski J.A., Tingey S.V., DNA polymorphisms amplified by arbitrary primers are useful as genetic markers, Nucleic Acids Res. 8 (1990) 6531-6535.

White T.J., Bruns T., Lee S., Taylor J., Amplification and direct sequencing of fungal ribosomal RNA genes for phylogenetics, in: Innis M.A., Gelfand D.H., Sninsky J.J., White T.J. (Eds.), PCR Protocols. A Guide to Methods and Applications, Academic Press, San Diego, CA, 1990, pp. 315-322. 